\title{
11. Effects of Adrenal Gland Constituents on the Fitness for High Altitude.
}

\author{
Preliminary report. \\ By Shoji IAwADARE. \\ Seventh Military Aviation Institute. \\ (Comm. by R. MAJimA, M.I.A., Jan. 12, 1945.)
}

Introduction.

Dr. S. Kawashima and his co-workers studied various Japanese aviation foods for years past and reported that a certain kind of nutritive factors would be specially effective in promoting the fitness for high altitude. The present author has recently become interested in the study of the the nutritive significance of adrenal gland constituents.

In 1937 Giragossintz and Sundstroem ${ }^{1)}$ studied the functional alteration in rats under the low pressure conditions and observed the symptoms very similar to those that in adrenalectonized animals.

In 1938 Armstrong and $\mathrm{Heim}^{2}$ reported the same findings in rabbits exposed to $379 \mathrm{~mm}$ pressure (18,000 feet altitude) for 4 hours daily.

Further, concerning the studies on a deficiency of cortico-adrenal secretion, it is also well known that cases suffering from Addison's disease are quite similar to those of cortico-adrenal insufficiency and the typical symptoms of it are asthenia, lassitude, lethargy, headache, debility, fatigue, and nervous irritability. As it is true that chronic altitude sickness may develop the similar symptoms as mentioned above, the following experiment was attempted to use adrenal gland constituents as nutritional factors for aviation food.

\section{Experimental.}

The experiment was carried out by feeding animals fed on diets containing some definite amounts of adrenal gland and then testing the time of survival at experimental high altitude. On carrying out this experiment, diets were prepared by mixing $10 \mathrm{~g}$ of basal ration in $20 \mathrm{cc}$ of water with $2 \mathrm{~g}$ of gland tissue.

Composition of basal diet:

$\begin{array}{lr}\text { unhulled rice powder } & 50 \% \\ \text { Wheat flour } & 25, \\ \text { Pure casein } & 15, \\ \text { Ebios } & 2, \\ \text { Soy bean oil } & 4, \\ \text { McCollum's salt mixture } & 2, \\ \text { Cod-liver oil } & 2,\end{array}$
(1939).

1), 2). Harry G. Armstrong: Principles and Practice of Aviation Medicine p. 286 
Diet I was prepared by adding to the basal diet dry gland tissue obtained by treating with methanol and evaporating at low temperature.

Diet II was prepared by adding fresh gland tissue preserved in acetone which was removed at low temperature.

Diet III was prepared by adding air dry gland tissue.

Die IV-control.

Animal experiment :

Mice previously fed on the basal diet described above were divided into four groups, each consisting of fine animals, and then were fed on various experimental diets (I-IV). After a certain period of feeding, animals were exposed to low pressure, and the time of survival at the altitude of 9-10 kilometers was estimated by observing the exposure period necessary to produce death. The results are shown in the following table.

\begin{tabular}{|c|c|c|c|c|c|c|c|}
\hline $\begin{array}{c}\text { Period treated } \\
\text { with the } \\
\text { experimental } \\
\text { diet }\end{array}$ & Altitude & $\begin{array}{l}\text { Diet } \\
\text { No. }\end{array}$ & $\begin{array}{l}\text { Body } \\
\text { weight } \\
\text { av. of } \\
\text { animals }\end{array}$ & $\begin{array}{l}\text { Tempe- } \\
\text { rature } \\
\text { of } \\
\text { room }\end{array}$ & $\begin{array}{l}\text { Time } \\
\text { spent in } \\
\text { reaching } \\
\text { the } \\
\text { altitude }\end{array}$ & \begin{tabular}{|} 
The \\
exposure \\
period \\
necessary \\
to \\
produce \\
death
\end{tabular} & $\begin{array}{l}\text { Time of } \\
\text { survivals } \\
\text { at the } \\
\text { altitude }\end{array}$ \\
\hline 1 day & $\begin{array}{l}10 \text { kilo- } \\
\text { meters }\end{array}$ & I & $14.4 \mathrm{~g}$ & $28^{\circ} \mathrm{C}$ & $150 \mathrm{sec}$. & 238 sec. & 88 sec. \\
\hline , & & I & 14.2 & $"$ & $"$ & 225 & 75 \\
\hline$"$ & $"$ & II & 13.4 & " & $"$ & 238 & 88 \\
\hline " & ” & II & 15.0 & " & , & 330 & 180 \\
\hline " & $\eta$ & III & 14.4 & , & " & 236 & 86 \\
\hline , & " & III & 13.6 & $"$ & " & 346 & 196 \\
\hline " & " & IV & 14.6 & , & $\eta$ & 206 & 56 \\
\hline , & " & IV & 13.8 & " & , & 208 & 58 \\
\hline 5 days & " & I & 14.4 & $26^{\circ} \mathrm{C}$ & $"$ & 262 & 112 \\
\hline , & $"$ & II & 14.8 & $"$ & $"$ & 568 & 418 \\
\hline$"$ & " & III & 14.6 & , & " & 260 & 110 \\
\hline " & " & IV & 14.0 & $"$ & , & 240 & 90 \\
\hline$"$ & $\begin{array}{ll}9 & \text { kilo- } \\
\text { meters }\end{array}$ & I & 16.3 & $28^{\circ} \mathrm{C}$ & $"$ & 508 & 358 \\
\hline$"$ & " & $\mathrm{I}$ & 14.3 & $"$ & " & 515 & 365 \\
\hline$"$ & , & II & 14.3 & $"$ & , & 690 & 540 \\
\hline$"$ & " & II & 13.0 & $"$ & $"$ & 980 & 830 \\
\hline$"$ & " & III & 15.0 & " & $"$ & 570 & 420 \\
\hline$"$ & $"$ & III & 15.0 & $"$ & " & 480 & 330 \\
\hline " & $"$ & IV & 12.5 & , & $"$ & 310 & 160 \\
\hline$"$ & , & IV & 14.0 & , & $"$ & 380 & 230 \\
\hline
\end{tabular}

From the experimental data, it has been ascertained that fresh adrenal gland constituents may be effective in promoting the fitness at high altitude.

The author wishes to express his sincere thanks to Dr. S. Kawashima for his kind advice and to Dr. Y. Sahashi for his able guidance during this work. $\mathrm{He}$ is also indebted to Fujisawa Company, Ltd., for their kindness in supplying him with materials. 